\title{
GENETIC VARIABILITY OF Triatoma flavida AND Triatoma bruneri (HEMIPTERA: REDUVIIDAE) BY RAPD-PCR TECHNIQUE
}

\author{
Jorge FrAGA(1), Jinnay RODRIGUEZ(2), Omar FUENTES(2), Yenin HERNÁNDEZ(2), Mayda CASTEX(2), Raul GONZALEZ(2) \& Aymé FERNÁNDEZ-CALIENES(1)
}

\begin{abstract}
SUMMARY
The Triatominae (Hemiptera:Reduviidae) contains the principal and potential Chagas disease vectors present in Mexico, Central America and South America. Triatoma flavida and T. bruneri are Cuban species. These species are closely related according to morphology and were considered synonyms until 1981, when they were separated on the grounds of external characters of the body and the morphology of male genitalia. The present study seeks to analyze genetic polymorphism of T. flavida and T. bruneri populations using RAPD techniques, and to assess the genetic relationship between these species. Ten random primers were used to evaluate the genetic variability among species using RAPD-PCR. The genetic flow among them was calculated. The dendrogram based on calculated Jaccard distances showed two clearly distinguishable clusters which coincided with the studied species. Within each species, moderate genetic differentiation (Fst 0.05-0.15) and migration rates $(\mathrm{N}>1)$ were found among populations, that reveal gene flow and genetic homogeneity. Between species, the Fst value showed a high genetic differentiation and the migration rate was insufficient to maintain genetic homogeneity, and confirmed the absence of gene flow between them. Our results confirm the genetic variability among T. flavida and T. bruneri species.
\end{abstract}

KEYWORDS: Triatominae; T. flavida; T. bruneri; RAPD; Genetic variability.

\section{INTRODUCTION}

The subfamily Triatominae (Hemiptera, Reduviidae) is currently divided in five tribes, 15 genera and 140 species $^{22}$. Most species occur in sylvatic ecotopes, associated with small nest-building mammals or birds, but several have made the transition to domestic habitats, where they feed on humans and domestic animals ${ }^{4}$. In Cuba there are four species of Triatominae recorded: Triatoma flavida (Neiva, 1911), Triatoma bruneri (Usinger, 1944), Bolbodera scabrosa (Valdés, 1910) and Triatoma rubrofasciata (De Geer, 1773).

T. flavida and T. bruneri are autochthonous species. T. flavida is a sylvatic species found in the western region of Cuba that presumably is attracted to houses by electric light. This species is the most abundant in Cuba and exhibits characteristics that increase its risk as a potential vector $^{15}$. T. bruneri has been found principally in the east region of Cuba, although LENT \& JURBERG $(1981)^{16}$ described its presence in the western region (Pinar del Rio). There are few reports of its habitat, biology and ecology, although domestic colonies have been encountered ${ }^{10}$.

Both species are closely related according to morphology, and between 1946 and 1981 they were considered synonymous. After 1981, they were separated on the grounds of external characters of the body and the morphology of male genitalia and considered different species ${ }^{16}$. HYPŠA et al. $(2002)^{13}$ published a phylogenetic study of 57 species of Triatominae and proposed the elevation of the "T. flavida complex" to the genus Nesotriatoma (including N. flavida, N. bruneri and N. obscura) according to the position of the clade $T$. flavida and T. bruneri, although this idea is not generally accepted ${ }^{22}$.

The analysis of genetic variation in Triatominae using molecular methods constitutes an essential element for populational analysis and also for taxonomic, ecology, biosystematic, epidemiologic, and evolutionary studies. The RAPD is a useful technique ${ }^{9}$; RAPD is a dominant marker and therefore the analysis makes certain underlying assumptions, however the technique has been used in studies of Triatominae such as: T. infestans ${ }^{19}, T$. dimidiate $^{21}, T$. brasiliensi $^{3}, T$. venos $^{24}, T$. vitticeps ${ }^{18}$, Rhodnius prolixus ${ }^{14,17}, R$. colombiensis ${ }^{14}$ and $R$. robustus $^{5}$ allowing discrimination of species, genetic variation, and estimates of gene flow between sylvatic, domiciliary and peri-domiciliary populations of these vectors.

The present study seeks to analyze genetic polymorphism of T. flavida and $T$. bruneri populations using the RAPD techniques and assess the genetic relationship between these species. 
FRAGA, J.; RODRIGUEZ, J.; FUENTES, O.; HERNÁNDEZ, Y.; CASTEX, M.; GONZALEZ, R. \& FERNÁNDEZ-CALIENES, A. - Genetic variability of Triatoma flavida and Triatoma bruneri (Hemiptera: Reduviidae) by RAPD-PCR technique. Rev. Inst. Med. Trop. São Paulo, 53(1): 19-24, 2011.

\section{MATERIAL AND METHODS}

Triatominae: In this study we used $31 \mathrm{~T}$. flavida adults collected in sylvatic habitats (caves) in different localities of Peninsula de Guanahacabibes, Pinar del Río province, and 29 T. bruneri adults captured inside houses in different localities of Holguín province (Table 1) (Fig. 1). All insects were classified as T. flavida and T. bruneri respectively in accordance with USINGER (1944) $)^{23}$ and LENT \& JURBERG $(1981)^{16}$. As out-group we used one T. rubrofasciata specimen from the collection from the Vector Control Department of the Institute of Tropical Medicine "Pedro Kouri" (IPK). This specimen was collected in the province of Santiago de Cuba.

DNA extraction: Each adult bug was examined individually. A leg was selected as source of genomic DNA using the potassium acetate modified method $^{6}$. The leg was ground to a fine powder with tissue grinders in a 1.5
$\mathrm{mL}$ microcentrifuge tube that contained liquid nitrogen. After grinding, the liquid nitrogen was allowed to evaporate and the powder resuspended in $150 \mu \mathrm{L}$ of lysis buffer (20 mM tris- $\mathrm{HCl}, \mathrm{pH} 8.25,25 \mathrm{mM}$ EDTA, 25 $\mathrm{mM} \mathrm{NaCl}, 1 \%$ SDS). The suspension was incubated with $100 \mu \mathrm{g} / \mathrm{mL}$ of proteinase $\mathrm{K}$ (Boehringer Mannheim, Germany) for one hour at $56{ }^{\circ} \mathrm{C}$. Nucleic acids were extracted with $100 \mu \mathrm{L}$ of potassium acetate $3 \mathrm{M}$, ice incubation for one hour and centrifugation at $8000 \mathrm{xg}$ for $10 \mathrm{~min}$ at $4{ }^{\circ} \mathrm{C}$. The DNA was precipitated by adding two volumes of absolute ethanol containing $0.3 \mathrm{M}$ sodium acetate and placed at $-20{ }^{\circ} \mathrm{C}$ for 30 minutes. The precipitated DNA was centrifuged at $10000 \mathrm{xg}$ for $20 \mathrm{~min}$. and the pellet washed in $70 \%$ ethanol. After air drying, the DNA was dissolved in $50 \mu \mathrm{L}$ tris-EDTA buffer (TE) $(1 \mathrm{mM}$ tris- $\mathrm{HCl} \mathrm{pH} 8.0,1 \mathrm{mM}$ EDTA $\mathrm{pH}$ 8.0). Any remaining RNA was eliminated with $\mathrm{RNaseH}$ (Boehringer Mannheim, Germany) and the suspension was incubated for one hour at 37 ${ }^{\circ} \mathrm{C}$. After extraction with equal volume of chloroform-isoamyl alcohol (24: 1 ), the aqueous phase was conserved at $-20{ }^{\circ} \mathrm{C}$. The DNA concentration

Table 1

Data of T. flavida and T. bruneri populations studied

\begin{tabular}{|c|c|c|c|c|}
\hline Specie & Number of specimens (Origin) & Sex & Collection site & Municipality, Province. \\
\hline \multirow[t]{31}{*}{ T. flavida } & $34(\mathrm{~S})$ & $\mathrm{F}$ & Caimanera & Guanahacabibes, Pinar del Río \\
\hline & $\mathrm{C}(\mathrm{S})$ & M & Caimanera & Guanahacabibes, Pinar del Río \\
\hline & $35(\mathrm{~S})$ & M & Caimanera & Guanahacabibes, Pinar del Río \\
\hline & $36(S)$ & $\mathrm{F}$ & Caimanera & Guanahacabibes, Pinar del Río \\
\hline & $37(\mathrm{~S})$ & M & Caimanera & Guanahacabibes, Pinar del Río \\
\hline & $38(\mathrm{~S})$ & M & Caimanera & Guanahacabibes, Pinar del Río \\
\hline & $39(\mathrm{~S})$ & $\mathrm{F}$ & Caimanera & Guanahacabibes, Pinar del Río \\
\hline & $40(\mathrm{~S})$ & $\mathrm{F}$ & Caimanera & Guanahacabibes, Pinar del Río \\
\hline & $108(\mathrm{~S})$ & $\mathrm{F}$ & Casito & Guanahacabibes, Pinar del Río \\
\hline & $127(\mathrm{~S})$ & $\mathrm{F}$ & Casito & Guanahacabibes, Pinar del Río \\
\hline & $109(\mathrm{~S})$ & M & Casito & Guanahacabibes, Pinar del Río \\
\hline & $128(\mathrm{~S})$ & M & Casito & Guanahacabibes, Pinar del Río \\
\hline & $48(S)$ & M & Suerte amparo & Guanahacabibes, Pinar del Río \\
\hline & $110(\mathrm{~S})$ & M & Suerte amparo & Guanahacabibes, Pinar del Río \\
\hline & $111(\mathrm{~S})$ & $\mathrm{F}$ & Suerte amparo & Guanahacabibes, Pinar del Río \\
\hline & $49(\mathrm{~S})$ & $\mathrm{F}$ & Motor del Veral & Guanahacabibes, Pinar del Río \\
\hline & $50(\mathrm{~S})$ & $\mathrm{F}$ & Motor del Veral & Guanahacabibes, Pinar del Río \\
\hline & $107(\mathrm{~S})$ & M & Helicoptero & Guanahacabibes, Pinar del Río \\
\hline & $115(\mathrm{~S})$ & M & Helicoptero & Guanahacabibes, Pinar del Río \\
\hline & $112(\mathrm{~S})$ & $\mathrm{F}$ & La sorda & Guanahacabibes, Pinar del Río \\
\hline & $113(\mathrm{~S})$ & $\mathrm{F}$ & La sorda & Guanahacabibes, Pinar del Río \\
\hline & $106(\mathrm{~S})$ & $\mathrm{F}$ & Frances & Guanahacabibes, Pinar del Río \\
\hline & $114(\mathrm{~S})$ & M & Frances & Guanahacabibes, Pinar del Río \\
\hline & $117(\mathrm{~S})$ & M & Frances & Guanahacabibes, Pinar del Río \\
\hline & $118(\mathrm{~S})$ & $\mathrm{F}$ & Frances & Guanahacabibes, Pinar del Río \\
\hline & $43(\mathrm{~S})$ & $\mathrm{F}$ & La Barca & Guanahacabibes, Pinar del Río \\
\hline & $44(\mathrm{~S})$ & M & La Barca & Guanahacabibes, Pinar del Río \\
\hline & $45(\mathrm{~S})$ & $\mathrm{F}$ & La Barca & Guanahacabibes, Pinar del Río \\
\hline & $46(S)$ & M & La Barca & Guanahacabibes, Pinar del Río \\
\hline & $33(\mathrm{~S})$ & $\mathrm{F}$ & Iguana & Guanahacabibes, Pinar del Río \\
\hline & $116(\mathrm{~S})$ & M & Iguana & Guanahacabibes, Pinar del Río \\
\hline
\end{tabular}




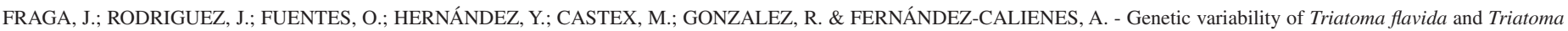
bruneri (Hemiptera: Reduviidae) by RAPD-PCR technique. Rev. Inst. Med. Trop. São Paulo, 53(1): 19-24, 2011.

Table 1

Data of T. flavida and T. bruneri populations studied (cont.)

\begin{tabular}{|c|c|c|c|c|}
\hline Specie & Number of specimens (Origin) & Sex & Collection site & Municipality, Province. \\
\hline \multirow[t]{29}{*}{ T. bruneri } & 202 (D) & $\mathrm{F}$ & Coto & Urbano Noris, Holguín \\
\hline & 203 (D) & F & Coto & Urbano Noris, Holguín \\
\hline & 204 (D) & M & Coto & Urbano Noris, Holguín \\
\hline & 205 (D) & $\mathrm{F}$ & Coto & Urbano Noris, Holguín \\
\hline & 206 (D) & M & Coto & Urbano Noris, Holguín \\
\hline & 207 (D) & $\mathrm{F}$ & Coto & Urbano Noris, Holguín \\
\hline & 208 (D) & F & Coto & Urbano Noris, Holguín \\
\hline & 209 (D) & M & Coto & Urbano Noris, Holguín \\
\hline & 210 (D) & $\mathrm{F}$ & Coto & Urbano Noris, Holguín \\
\hline & 211 (D) & $\mathrm{F}$ & Coto & Urbano Noris, Holguín \\
\hline & 212 (D) & M & Coto & Urbano Noris, Holguín \\
\hline & 213 (D) & $\mathrm{F}$ & Coto & Urbano Noris, Holguín \\
\hline & 214 (D) & M & Coto & Urbano Noris, Holguín \\
\hline & 215 (D) & M & Coto & Urbano Noris, Holguín \\
\hline & 216 (D) & M & Coto & Urbano Noris, Holguín \\
\hline & 217 (D) & $\mathrm{F}$ & Coto & Urbano Noris, Holguín \\
\hline & 218 (D) & $\mathrm{F}$ & Coto & Urbano Noris, Holguín \\
\hline & 219 (D) & M & Coto & Urbano Noris, Holguín \\
\hline & 220 (D) & $\mathrm{F}$ & Coto & Urbano Noris, Holguín \\
\hline & 221 (D) & M & Coto & Urbano Noris, Holguín \\
\hline & 222 (D) & F & Iberia & Gibara, Holguín \\
\hline & 223 (D) & M & Iberia & Gibara, Holguín \\
\hline & 224 (D) & M & Iberia & Gibara, Holguín \\
\hline & 225 (D) & M & Iberia & Gibara, Holguín \\
\hline & 226 (D) & M & Guanina & Mayari, Holguín \\
\hline & 227 (D) & M & Guanina & Mayari, Holguín \\
\hline & 228 (D) & M & Dos Hermanas & Cacocum, Holguín \\
\hline & 229 (D) & M & Dos Hermanas & Cacocum, Holguín \\
\hline & 230 (D) & M & Dos Hermanas & Cacocum, Holguín \\
\hline
\end{tabular}

S: sylvatic; D: domestic

was estimated spectrophotometrically by reading absorbance at $260 \mathrm{~nm}$ and the purity of the sample was examined by electrophoresis with a $0.8 \%$ agarose gel in TBE buffer (TBE 0.5x) (0.045 M tris-borate, 0,001 M EDTA) containing ethidium bromide $(0.5 \mathrm{mg} / \mathrm{mL})$ with visualization using a UV transilluminator (Macrovue 2011, LKB).

RAPD-PCR: RAPD protocol previously optimized ${ }^{8}$, was used for the amplification of random DNA markers to reveal genetic diversity among T. flavida and T. bruneri populations using ten oligonucleotides primers (OPA-1 to 10). The amplification was performed in a final volume of $25 \mu \mathrm{L}$ containing $2.5 \mu \mathrm{L}$ of $10 \mathrm{x}$ PCR reaction buffer (Promega, USA) and $200 \mu \mathrm{M}$ of each dNTPs (Promega, USA) with 5 pmol of primer, $2.5 \mathrm{mM}$ of $\mathrm{MgCl}_{2}$, $25 \mathrm{ng}$ of template DNA and $2.0 \mathrm{U}$ of Taq DNA polymerase (Promega, USA). Negative controls for each assay contained all components above, except template DNA of T. flavida and T. bruneri, with the objective of discarding any contamination. In a thermocycler (Perkin Elmer, USA) the reactions were amplified as follows: initial denaturation at $94{ }^{\circ} \mathrm{C}$ for five min, followed by 45 repetitions of one min at $94{ }^{\circ} \mathrm{C}$, one min at $36{ }^{\circ} \mathrm{C}$ and two min at $72{ }^{\circ} \mathrm{C}$. In the final cycle, the extension step was of $15 \mathrm{~min}$. Analysis was done by electrophoresis in $1.2 \%$ agarose gels in TBE buffer containing ethidium bromide $(0.5 \mathrm{mg} / \mathrm{mL})$ with visualization using a UV transiluminator. The presence or absence of each band was scored visually.

Genetic polymorphism: For the analysis, it is assumed that (a) the T. flavida and T. bruneri insects are in Hardy-Weinberg equilibrium and therefore no selection processes favouring any particular genotype, (b) RAPD markers segregate in a Mendelian fashion with constant evolution or substitution rate and (c) recessive (band absent) alleles are identical in state among and between individuals. Individual bands were scored as present or absent ( 1 or 0 , respectively) for each specimen and the Jaccard similarity coefficient $(\mathrm{Sj})$ was used, as follows: $\mathrm{Sj}=\mathrm{a} /(\mathrm{a}+\mathrm{b}+\mathrm{c})$ where $" a{ }^{\circ}$ represents the number of shared bands, "b" represents the number of bands present in specimen 1 and absent in specimen 2 and "c" represents the number of bands present in specimen 2 and absent in specimen 1. 


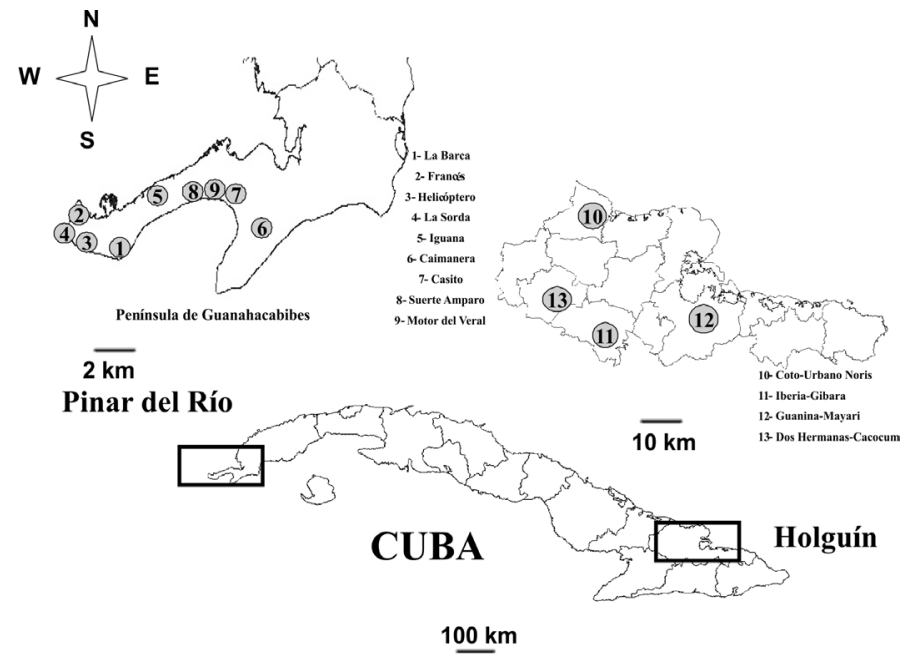

Fig. 1 - Geographical location of the capture sites of Triatominae studied.

Phylogenetic relationships were determined by the group-average clustering strategy or the unweighted pair group method with arithmetic averages (UPGMA) using FreeTree, version 0.9.1.59. ${ }^{20}$. Dendograms were constructed based on data from ten primers and bootstrap analysis with 2000 replicates.

Genetic flow: WRIGHT's (1951) ${ }^{26}$ and WEIR \& COCKERHAM's $(1984)^{25}$ fixation index (Fst) and the effective migration rate $(\mathrm{Nm})$ were estimated by RAPDFST ${ }^{2}$. The analysis was made with the assumption that the mutation rates are lower than the insect migration rates.

\section{RESULTS}

From the 115 reproducible RAPD bands generated, 85 bands showed polymorphism among species and 30 were monomorphic.

Comparison of the RAPD profiles showed the presence of speciesspecific bands. Amplification with OPA-2 primer (Fig. 2A) revealed a genetic marker of $630 \mathrm{bp}$ in all individuals of T. bruneri that was absent from T. flavida. Also a 700 bp genetic marker was observed in all T. flavida individuals, that was absent in T. bruneri. The RAPD banding patterns obtained with OPA-4 primers (Fig. 2B) showed a genetic marker of 500 bp in all T. flavida and 750 bp genetic marker in all T. bruneri individuals.

The dendrogram based on Jaccard distances (Fig. 3) showed two clearly distinguishable clusters: (1) T. flavida; (2) T. bruneri suggested by high bootstrap value (100\%). The tree also shows a correlation with geographic origin within each species. Two main groups can be recognized within T. flavida group with high bootstrap value (89 and $80 \%$, respectively), they matched with the populations captured in areas from west and east of Guanahacabibes. T. bruneri individuals are grouped in three major clusters corresponding to the individuals of Coto, Iberia-Dos Hermanas and Guanina (Fig. 1).

The heterogeneity obtained in the banding patterns suggests high genetic differentiation between $T$. flavida and T. bruneri. The individuals of T. flavida group with a genetic distance of 0.1217 (Similarity

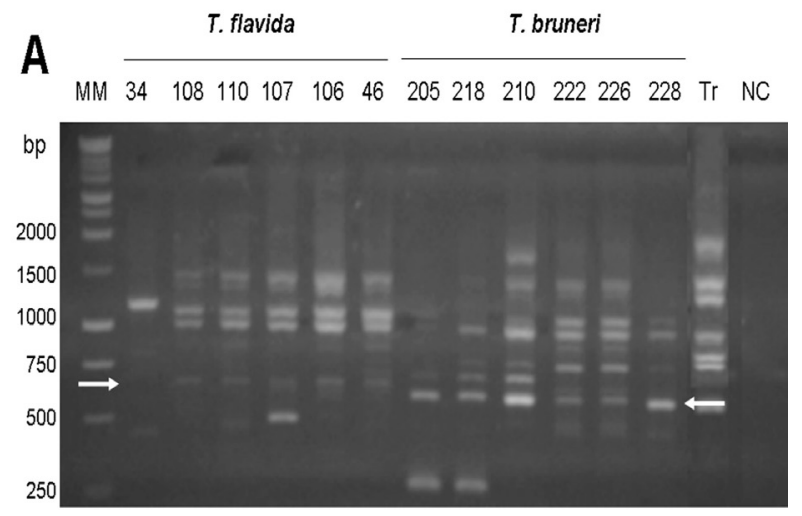

\section{B}

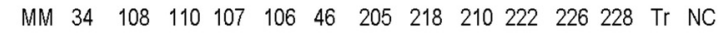

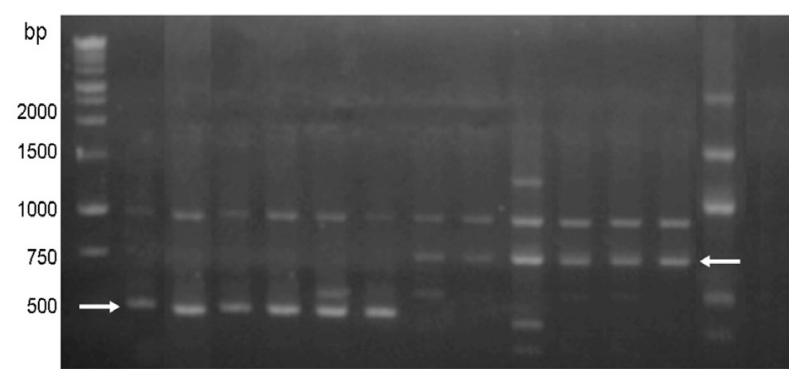

Fig. 2 - RAPD banding patterns obtained from 12 Triatominae using OPA-2 (A) and OPA-4 (B) primers. Lane MM. Molecular Weight Marker $1 \mathrm{kbp}$ (Promega, USA); Lanes 34, 108, 110, 107, 106, 46: T. flavida bugs; Lanes 205, 218, 210, 222, 226, 228: T. bruneri bugs; Lane Tr: T. rubrofasciata; NC: Negative control without DNA. Arrows represent the specie specific RAPD genetic markers.

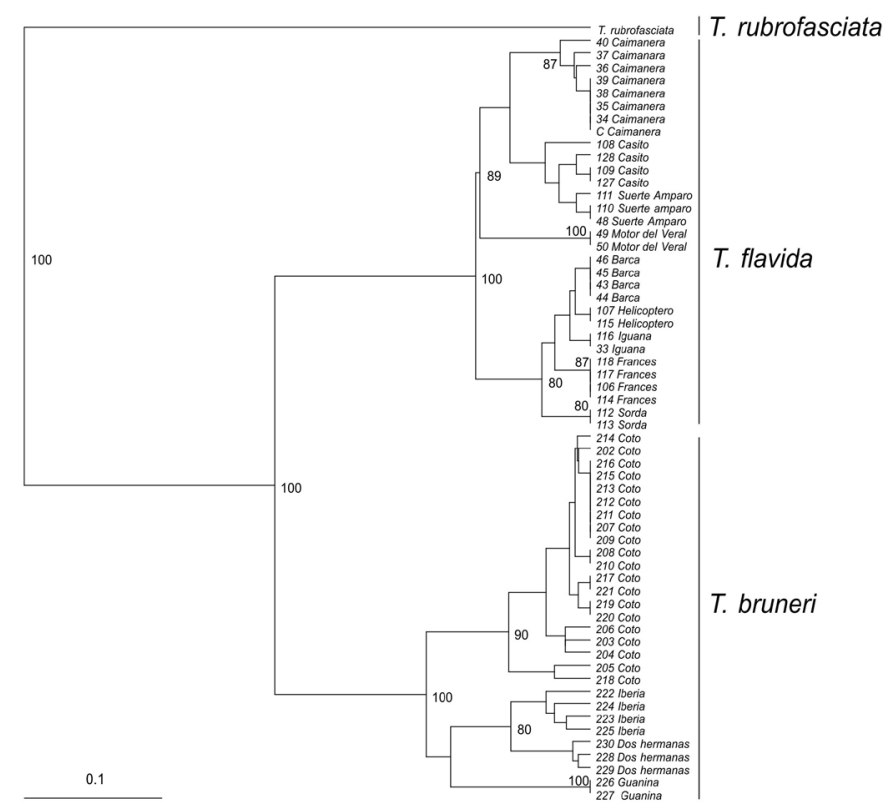

Fig. 3 - Dendogram generated for specimens populations of T. flavida and T. bruneri using Jaccard's dissimilarity index and the UPGMA algorithm. T.rubrofasciata: out-group. Bootstrap support of the branches was inferred from 2000 replicates, and is given in percentages at the internodes when exceeding $80 \%$. 


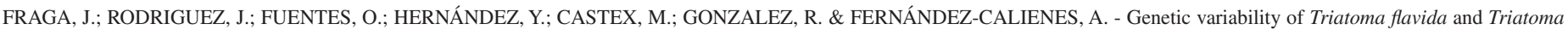
bruneri (Hemiptera: Reduviidae) by RAPD-PCR technique. Rev. Inst. Med. Trop. São Paulo, 53(1): 19-24, 2011.

Table 2

Fixation index and effective migration rate values among T. flavida and T. bruneri species

\begin{tabular}{llccc}
\hline Methodologies & & Among T. flavida populations & Among T. bruneri populations & Among T. flavida and T.bruneri \\
\hline Wright & Fst & 0.055 & 0.090 & 0.36 \\
& Nm & 8.4 & 7.6 & 0.7 \\
\multirow{2}{*}{ Weir and Cockerham } & Fst & 0.052 & 0.087 & 0.35 \\
& Nm & 8.6 & 7.2 & 0.6 \\
\hline
\end{tabular}

Coefficient $87.83 \%$ ) while $T$. bruneri group with a genetic distance of 0.1607 (Similarity Coefficient $83.92 \%$ ). T. bruneri presents higher genetic variability when compared to T. flavida. However, within each species the Fst value showed a moderate genetic differentiation (Fst 0.05-0.15), according to Wright's classification (WRIGHT, 1978) ${ }^{27}$ and migration rate $(\mathrm{Nm}>1)$ among populations that reveal gene flow and genetic homogeneity (Table 2).

The heterogeneity in the RAPD banding pattern suggests a high genetic differentiation between $T$. flavida and T. bruneri. The species separate with a genetic distance of 0.4614 (Similarity Coefficient $53.86 \%$ ). These results were corroborated by the fixation index and the effective migration rate. The Fst value showed a high genetic differentiation (Fst $>0.25)$ and the migration rate $(\mathrm{Nm}<1)$ was insufficient to maintain genetic homogeneity between both species (Table 2 ).

\section{DISCUSSION}

Triatominae appear to be a polyphyletic group, with generalist species displaying higher genetic and phenetic variation and specialist species showing relatively reduced population variability, probably associated with a series of genetic bottlenecks (founder effects) followed by drift and modest selection ${ }^{11}$.

RAPD markers are amplification products of DNA sequences using single, short and arbitrary oligonucleotide primers, and thus do not require prior knowledge of sequence. Low expense, efficiency in developing a large number of DNA markers in a short time and requirement for less sophisticated equipment has made the RAPD technique valuable although reproducibility of the RAPD profile is still the centre of debate. A major drawback of RAPD markers in population genetic studies of out breeding organisms is that they are dominant. Thus gene frequency estimates for such loci are necessarily less accurate than those obtained with codominant markers such as allozymes and RFLPs. Some authors suggested that two to 10 times more individuals need to be sampled for dominant markers to achieve the same degree of statistical power as codominant markers such as allozymes and RFLPs ${ }^{1}$. The assumption of homology between bands of apparently the same molecular weight from the same primer is potentially another problem for RAPD surveys. Homology between comigrating bands in different individuals is a good assumption when individuals are from the same population. This may not be true when individuals belong to different species or widely divergent populations. Because the chance of comigrating bands being homologous becomes less as populations diverge, it was suggested that RAPD analysis gives more accurate estimates between closely related populations and less accurate estimates for distantly related populations. RAPD data has been used for phylogenetic studies and generally supported existing taxonomies based on morphology, isozymes and RFLPs ${ }^{1}$.
For the first time we analyze the genetic variability among sylvatic T. flavida and domestic T. bruneri populations collected in the western and eastern regions of Cuba, respectively, using RAPD. We chose the OPA 1-10 primers because these primers were previously used in studies of genetic polymorphism between $16 \mathrm{~T}$. flavida specimens from nine populations. The polymorphisms obtained with these primers were reproducible among samples of the same specimens ${ }^{6-7}$.

In our work the heterogeneity observed in the RAPD banding patterns and the genetic distance obtained among the species together with the estimates of Fst and $\mathrm{Nm}$ allows concluding that T. flavida and T. bruneri have a high genetic variability although there is evidence of spatial structuring of their populations. These results are in concordance with LENT \& JURBERG $(1981)^{16}$ who proposed separation of the two species based on characters of the external body and morphology of genitalia.

In the present study, we found low genetic variability (Genetic distance 0.1217 ) among sylvatic T. flavida individuals. Fst value showed a moderate genetic differentiation (Fst 0.05-0.15) and migration rate ( $\mathrm{Nm}>1)$ among populations, that reveal gene flow and genetic homogeneity. This result is similar with our previous study carried out with a lower number of T. flavida individuals (16 bugs) from nine populations collected in the same place (Peninsula de Guanahacabibes, Pinar del Río, western region of Cuba). In this study we reported low genetic variability (Genetic distance 0.107), small genetic differentiation (Fst 0.030) and migration rate $(\mathrm{N}>1)$ that reveal gene flow and genetic homogeneity between sylvatic individuals of this specie ${ }^{7}$. T. bruneri individuals are more variable than sylvatic $T$. flavida. Also among populations this specie showed gene flow and genetic homogeneity. The higher genetic variability of the domiciliated T. bruneri may be due to a recent process of domestication.

Although the relevance of T. flavida and T. bruneri in the transmission of Chagas disease is currently unknown, and no natural infection with trypanosomes has been reported, T. flavida has been shown capable of transmitting the disease under laboratory conditions ${ }^{12}$. These two species should be considered in future epidemiological surveillance programmes.

\section{RESUMEN}

\section{Variabilidad genética de Triatoma flavida y Triatoma bruneri (Hemiptera: Reduviidae) mediante la técnica de RAPD-PCR}

La subfamilia Triatominae (Hemiptera: Reduviidae) agrupa a los vectores principales y potenciales de la Enfermedad de Chagas, presente en México, Centroamérica y Sudamérica, Triatoma flavida y T. bruneri son especies autóctonas cubanas. Estas especies están muy relacionadas desde el punto de vista morfológico y por ello fueron consideradas sinonimas hasta el 1981, cuando fueron separadas teniendo en cuenta los caracteres 
FRAGA, J.; RODRIGUEZ, J.; FUENTES, O.; HERNÁNDEZ, Y.; CASTEX, M.; GONZALEZ, R. \& FERNÁNDEZ-CALIENES, A. - Genetic variability of Triatoma flavida and Triatoma bruneri (Hemiptera: Reduviidae) by RAPD-PCR technique. Rev. Inst. Med. Trop. São Paulo, 53(1): 19-24, 2011.

externos del cuerpo y la morfología de la genitalia del macho. El presente trabajo pretende confirmar el polimorfismo genético entre las poblaciones selváticas de T. flavida y domiciliadas de T. bruneri utilizando la técnica de RAPD-PCR. Un total de 10 cebadores al azar fueron usados para evaluar la variabilidad genética entre las especies usando la técnica de RAPD-PCR, calculándose el flujo genético entre las especies. El dendrograma obtenido, basado en la distancia genética de Jaccard, mostró dos grupos que coinciden con las especies estudiadas. Dentro de cada especie estudiada se encontró una moderada diferenciación genética (Fst 0.05-015) y tasas de migración $(\mathrm{N}>1)$ que revelan flujo genético y homogeneidad genética. Entre las especies estudiadas los valores de Fst muestran una alta diferenciación genética y tasas de migración insuficientes para mantener homogeneidad genética y confirman la ausencia de flujo genético entre ellas. Estos resultados confirman la variabilidad genética entre ambas especies.

\section{ACKNOWLEDGEMENTS}

This work was supported in part by grants from European Community Latin American Triatominae Research Network (ECLAT).

\section{AUTHOR CONSTRIBUTION}

JR, OF, YH, MC and RG collected and classified the Triatominaes; JF, AFC, JR performed the laboratory work; JF, JR, OF, YH, MC, RG and AFC analyzed and interpreted the results; JF, JR and OF drafted the manuscript; JF, YH, OF, YH, MC, AFC critically revised the manuscript.

\section{REFERENCES}

1. Bardakci F. Random amplified polymorphic DNA (RAPD) markers. Turk J Biol. 2001;25:185-96.

2. Black WC. IV RAPDFST. A FORTRAN program to estimate $F(S T)$ and effective migration rates among subpopulations using RAPD-PCR files. Fort Collins: Colorado State University; 1997.

3. Borges EC, Dujardin JP, Schofield CJ, Romanha AJ, Diotaiuti L. Dynamics between sylvatic, peridomestic and domestic populations of Triatoma brasiliensis (Hemiptera: Reduviidae) in Ceará State, Norheastern Brazil. Acta Trop. 2005;93:119-26.

4. Dujardin JP, Steindel M, Chavez T, Machane M, Schofield CJ. Changes in the sexual dimorphism of Triatominae in the transition from natural to artificial habitats. Mem. Inst. Oswaldo Cruz. 1999;94:565-9.

5. Feliciangeli MD, Dujardin JP, Bastrenta B, Mazzarri M, Villegas J, Flores M, et al. Is Rhodnius robustus (Hemiptera: Reduviidae) responsible for Chagas disease transmission in Western Venezuela? Trop Med Int Health. 2002;7:280-7.

6. Fraga J, Rodríguez J, Fuentes O, Castex M, Fernández-Calienes A. Comparación entre cinco métodos para la extracción de ADN de Triatomíneos: su utilización en la técnica de ADN polimórfico amplificado al azar (RAPD). Rev Cubana Med Trop. 2004;56: 208-13.

7. Fraga J, Rodríguez J, Fuentes O, Castex M, Fernández-Calienes A. Variabilidad genética de poblaciones de Triatoma flavida (Hemiptera: Reduviidae) en la península de Guanahacabibes. Rev Cubana Med Trop. 2009;61:88-96.

8. Fraga J, Rodríguez J, Fuentes O, Fernández-Calienes A, Castex M. Optimization of random amplified polymorphic DNA techniques for use in genetic studies of Cuban Triatominae. Rev Inst Med Trop Sao Paulo. 2005;47:295-300.

9. García AL, Carrasco HJ, Schofield CJ, Russell J, Frame IA, Valente SAS, et al. Random amplification of polymorphic DNA as a tool for taxonomic studies of Triatomine bugs (Hemiptera: Reduviidae). J Med Entomol. 1998;35:38-45.
10. González AM. Estrategia participativa para determinar triatomineos en viviendas del Municipio Puerto Padre. [Tesis para el Titulo de Master]. Habana: Instituto de Medicina Tropical Pedro Kourí; 2008. 60 p.

11. Guhl F, Schofield CJ. Population genetics and control of Triatominae. Parasit Today. 1996;12:169-70.

12. Hernández-Pombo L, Diaz-Canel O. Triatomineos capaces de transmitir Trypanosoma cruzi en Cuba. Rev Cubana Med Trop. 1976;28:101-4.

13. Hypša V, Tietz DF, Zrzavý J, Rego ROM, Galvao G, Jurberg J. Phylogeny and biogeography of Triatominae (Hemiptera: Reduviidae): molecular evidence of a New World origin of the Asiatic clade. Mol Phylogenet Evol. 2002;23:447-57.

14. Jaramillo C, Montaña MF, Castro LR, Vallejo GA, Guhl F. Differentiation and genetic analysis of Rhodnius prolixus and Rhodnius colombiensis by rDNA and RAPD amplification. Mem Inst Oswaldo Cruz. 2001;96:1043-8.

15. Jiménez-Ozete H. Observaciones sobre la biología de Triatoma flavida, Neiva, 1911 en Cuba. Rev Cubana Med Trop. 1981;33:42-50.

16. Lent H, Jurberg J. As especies insulares de Cuba do genero Triatoma Laporte (Hemiptera, Reduviidae). Rev Bras Biol. 1981;41: 431-9.

17. López DC, Jaramillo C, Guhl F. Estructura poblacional y variabilidad genética de Rhodnius prolixus (Hemiptera: Reduviidae) procededente de diferentes áreas geográficas de Colombia. Biomédica. 2007;27:28-39.

18. Moreira de Souza R, Barbosa SE, Sonoda IV, Azeredo BMV, Romanha AJ, Diotaiuti L. Population dynamics of Triatoma vitticeps (Stal, 1859) in Itanhomi, Minas Gerais, Brazil. Mem Inst Oswaldo Cruz. 2008;103:14-20.

19. Norieau F, Bastrenta B, Catalá S, Dujardin JP, Panzera F, Torres M, et al. Sylvatic population of Triatoma infestans from the Bolivian Chaco: from field collection to characterization. Mem Inst Oswaldo Cruz. 2000;95(Suppl 1):119-22.

20. Pavlícek A, Hrdá S, Flegr J. Free-tree--freeware program for construction of phylogenetic trees on the basis of distance data and bootstrap/jackknife analysis of the tree robustness. Application in the RAPD analysis of genus Frenkelia. Folia Biol (Praha). 1999;45:97-9.

21. Ramírez C, Jaramillo CA, Del Pilar Delgado M, Pinto NA, Aguilera G, Guhl F. Genetic structure of sylvatic, peridomestic and domestic population of Triatoma dimidiata (Hemiptera: Rediviidae) from and endemic zone of Boyaca, Colombia. Acta Trop. 2005;93:23-9.

22. Schofield CJ, Galvão C. Classification, evolution and species groups within the Triatominae. Acta Trop. 2009;110:88-100.

23. Usinger RL. The Triatominae of North and Central America and West Indies and their public health significance. Public Health Bull. 1944; 288:81-3.

24. Vargas E, Espitia C, Patiño C, Pinto N, Aguilera G, Jaramillo C, et al. Genetic structure of Triatoma venosa (Hemiptera: Reduviidae): a molecular and morphometric evidence. Mem Inst Oswaldo Cruz. 2006;101:39-45.

25. Weir BS, Cockerham CC. Estimating F-statistics for the analysis of population's structure. Evolution. 1984;38:1358-70.

26. Wright S. Evolution in Mendelian populations. Genetics. 1951;16:97-159.

27. Wright S. Evolution and the genetics of populations. V. 4. Variability within and among natural populations. Chicago:University of Chicago Press; 1978.

Received: 28 August 2010

Accepted: 11 November 2010 